\title{
EVENTS
}

ВСЕРОССИЙСКАЯ СТУДЕНЧЕСКАЯ НАУЧНОТЕОРЕТИЧЕСКАЯ КОНФЕРЕНЦИЯ

С МЕЖДУНАРОДНЫМ УЧАСТИЕМ «МЕЖКУ ДЬТУРНАЯ КОММУНИКАЦИЯ В ЕДИНОМ ОБРАЗОВАТЕЛЬНОМ ПРОСТРАНСТВЕ: ПРОБЛЕМЫ И ПЕРСПЕКТИВЫ»

\begin{abstract}
ALL-RUSSIAN STUDENT SCIENTIFIC AND THEORETICAL CONFERENCE WITH INTERNATIONAL PARTICIPATION “INTERCULTURAL COMMUNICATION IN A UNIFIED EDUCATIONAL SPACE: PROBLEMS AND PROSPECTS"
\end{abstract}

On the 22th of March, 2019 on the basis of the Ryazan State Medical University named after academician I.P. Pavlov held the All-Russian Student ScientificTheoretical Conference with international participation "Intercultural communication in a unified educational space: problems and prospects". The conference was organized by the Department of Latin and Russian languages with the participation of the Department of Foreign Languages. The aim of the conference was to present the results of scientific researches of students and young scientists and to attract the attention of the scientific community to topical issues of intercultural communication.

\section{The main directions of the conference:}

- Actual psycholinguistic and linguocultural aspects of the study of intercultural communication.

- The role of the Russian language in intercultural communication.

- Languages for special purposes and intercultural professional 
communication.

- Intercultural communication in the modern information society.

- Polycultural education and problems of sociocultural adaptation of foreign students.

The conference was attended by 143 people - representatives of 12 universities in Russia. The participants and speakers were citizens of 19 countries: Russia, Algeria, Bulgaria, Vietnam, Ghana, India, Cameroon, China, Congo, Kyrgyzstan, Moldova, Nigeria, Pakistan, Syria, the USA, Tajikistan, Tunisia, Turkmenistan, Uzbekistan. Reports were presented in Russian, English and French.

The conference was opened by the Vice-Rector for Research and Innovative Development of the Ryazan State Medical University named after academician I.P. Pavlov, Ph.D., professor Igor Alexandrovich Suchkov, who noted the particular relevance of the areas of the conference and the need to hold such an event annually. Welcoming remarks were made by the Dean of the Faculty for Teaching Foreign Students of RyazSMU, Ph.D., associate professor Viktor Grigorievich Okorokov. He thanked the organizers of the conference for the opportunity to discuss the most important issues of intercultural communication.

At the plenary meeting, Sulitsa Oleg Andreevich, an expert of the Federal Agency for Youth Affairs, a member of the Council for the harmonization of interethnic relations under the Governor of the Ryazan Region, the chairman of the Ryazan regional branch of the All-Russian Interethnic Union of Youth spoke. His report "International events as an effective format of intercultural communication in the youth environment" aroused great interest among all those present in the hall. The speech of Olga Petrovna Bykova, Doctor of Pedagogical Sciences, professor, professor of the Department of Linguistics, Moscow State University of Geodesy and Cartography was devoted to the role of a teacher of Russian as a foreign language in the cultural integration of foreign students. Post-graduate student of the Department of Russian language and its teaching methods at Ryazan State University, lecturer at the Department of Latin and Russian Languages, RyazSMU Elena Logacheva made a presentation "The role of the Russian language in intercultural communication". Lecturer of the Department of Foreign Languages of the RyazSMU Anna Vladimirovna Ilyushina made a presentation "Intercultural competence in the context of increasing the academic mobility of medical students". At the breakout sessions, 58 reports on the main areas of the conference were heard and discussed. 
ДАТА ПОСТУПДЕНИЯ: 01.04.2019

ДАТА ПРИНЯТИЯ В ПЕЧАТЬ: 06.06.2019

\section{ССЫДКА ДЛЯ ЦИТИРОВАНИЯ:}

Всероссийская студенческая научно-теоретическая конференция с международным участием «Межкультурная коммуникация в едином образовательном пространстве: проблемы и перспективы» // Дичность в меняющемся мире: здоровье, адаптация, развитие: сетевой журн. 2019. Т.7, № 2 (25). Доступно по ссылке:

http://humjournal.rzgmu.ru/art\&id=383 Ссылка активна на чч.мм.гтгг. doi: 10.23888/humJ20192428-430
PAPER RECEIVED:01.04.2019

PAPER ACCEPTED:06.06.2019

\section{REFERENCE FOR CITING:}

All-Russian student scientific and theoretical conference with international participation "Intercultural communication in a unified educational space: problems and prospects". Personality in a changing world: health, adaptation, development: a network journ. 2019; 7 (2) Available at: http://humjournal.rzgmu.ru/art\&id=383 Accessed: dd Month yyyy. doi: 10.23888/humJ20192428430 